\title{
Corporate Social Responsibility of Commercial Bank in Bangladesh: A Comparative Study on Nationalized and Private Banks
}

\author{
Md. Touhidul Islam ${ }^{1 *}$, Md. Tareq Hasan ${ }^{2}$ \\ ${ }^{1}$ Research Fellow, Department of Business Administration, Pabna University of Science \& Technology, Pabna-6600, BANGLADESH \\ ${ }^{2}$ MBA Student, Department of Business Administration, Pabna University of Science \& Technology, Pabna-6600, BANGLADESH \\ *E-mail for correspondence: touhidpust@gmail.com
}

Received: Feb 06, 2016

Accepted: Feb 20, 2016

\begin{abstract}
Corporate social responsibility (CSR) refers to strategies corporations or firms conduct their business in a way that is ethical, society friendly and beneficial to community in terms of development. This research analyses the meaning of CSR based on some theories available in literature. CSR is evolving in its meaning and practice. The research discusses the role of CSR in community development. CSR movement has gathered great momentum over the past number of years and is now regarded as being at this most prevalent. CSR is presently one of the most discussed topics. The purpose of the study is to provide deep understanding about CSR benefit, accountability and show steps taken by the government. The study has been taken to observe different CSR areas of nationalized and private commercial banks and its contribution. This study found CSR practices of nationalized and private commercial banks. The study reveals that nationalized and private commercial banks are trying to swell their contribution in accordance with their performance.
\end{abstract}

Keywords: CSR, Accountability, Commercial Bank, Comparative Study

\section{INTRODUCTION}

Today, the world faces lot of challenges ranging from environmental degradation through poverty and human rights, to energy and resource supply issues. Our social responsibility policy focuses on using our capabilities as a business to improve lives and sustain our planet through contributions to local communities and society at large. Corporate Social Responsibility is not only an act for humanity but also to provide good working environment to an organization's employees, to pay just remuneration, to give regular leave, to care as a human beings and to care environment of the society (The Daily Prothom-Alo). Corporate social Responsibility is associated with corporate governance and ethical business procedure. Good corporate governance is expected to underpin effective and efficient corporate social responsibility within banking sector. We observe, from our content analysis of the annual reports within the Bangladesh banking industry that the corporate social responsibility disclosures focus on initiatives undertaken to support different sector.

The purpose of the study is to provide deep understanding of the practices of CSR of nationalized and private commercial banks in Bangladesh. The study has been taken to observe different sector (CSR areas) of
CSR of nationalized and private commercial banks and its contribution. The study reveals that nationalized and private commercial banks are trying to swell their contribution in accordance with their performance. A properly implemented CSR concept can bring along a variety of competitive advantages, such as enhanced access to capital and markets, increased sales and profits, operational cost savings, improved productivity and quality, efficient human resource base, improved brand image and reputation, enhanced customer loyalty, better decision making and risk management processes.

CSR is good for all. Studies show that what is good for the environment, workers, and community is also good for the company. The benefits of practicing CSR include; Improved financial performance, Reduce risk exposure, Identification of new products and services, Enhanced brand images, Increased customer loyalty, Improved recruitment and retention performance, Tax waiver on socially and environmentally responsible business lines, Reduced costs through environment best practice leading to sustainable profitability. (Sources: current affairs).

So business needs to be engaged in CSR activities in their own interest. Besides fulfilling the ethical obligations, the banks can be immensely benefited from the new client bases created as a result of CSR activities. Moreover, 
banks that mainly do business with the depositor's money cannot avoid responsibility to the society.

\section{Application of CSR in Bangladesh}

Under the developing country CSR application is the reasonable criteria like Bangladesh which to be applied in various purposes. Now a days it has been more emphasized by the different nationalized and private banks, different ministry, organization etc. which help to improve the per capital income, reduce the poverty, fair trade, sustainability, working conditions, child labor and human rights. In the point of view of business till now, most of the businesses in Bangladesh are family owned and first generation businesses The CSR applies in Bangladesh in its modern global terms, is relatively new. Corporate social responsibility within the banking sector in Bangladesh, The corporate social performance model is valuable as it provides the beginnings of a paradigm for the field. It is of interest in our study to identify whether corporate social responsibility disclosures made in the Bangladesh banking sector focus on economic responsibility, public responsibility or social responsiveness and similar nature might be able to pinpoint where Bangladesh lies in terms of evolutionary model.

\section{Literature Review}

Literature review creates the gap of the research. The researcher has comprehensively gone through the available literature relating to CSR. Generally it is used for improving theoretical framework for the study as well as justification of the study.

Corporate social responsibility is not the only ethical dilemma that financial institutions face in an atmosphere of corrupt corporate practice. These banking institutions are also concerned with commitment for sustainable development. A well-functioning banking sector of country can contribute directly to a healthy economy. CSR reporting of banking sector in Bangladesh is increasing and concern about the matter and significantly maintained in the annual report. Corporate Social Responsibility (CSR) reporting focuses vary by banking, by size, by sector and even by geographic region. For better and enhanced performance CSR rules and reporting implementation is thus now need, not merely demand. The study has taken an attempt to observe the CSR reporting practices of public and Private Commercial Banks in Bangladesh in consideration with annual report BB2009-2013. An in depth and comprehensive study on the performance of Bangladeshi banking sector on this subject is found very limited. An attempt is made here to present a brief review of practices CSR sectors area, amount, and work. One of the best known CSR model, presents bank's social obligation as comprising economic, legal, ethical and philanthropic responsibility (Gray, Javad, Power \& Sinclair, 2001).
In a comparative study on public and private commercial banks we analysis' of their capita, net earnings, practice of CSR in different sectors etc. in respect of annual report, different article, different research papers, questionnaire survey . It is found out that private commercial banks of country are more concern rather than public commercial banks about CSR. It is also found that the client or customer satisfaction has the mediating factor for banking service quality and the CSR is the most influential factor for the client or customer satisfaction. the purpose of this paper which explore the perception on Corporate Social Responsibility (CSR) according to the bankers and people perception and banking practice of public and private commercial banks. Those banks identify from quantitative analysis on collected questionnaires for Corporate Social Responsibility Practices of Commercial Banks CSR framework.

This study can help banking managers understand what should be done for the benefit of customers and the community for sustainability. From the above discussion it is clear that commercial public and private banks are fairly involved in the CSR activities. The CSR activities have a positive impact on the financial performance of banking long term. But comprehensive study is relating to know an insight in to CSR practices of public and private commercial banks.

\section{Statement of the Problem}

CSR are performed by private and nationalized commercial banks, but there is a different between two type's banks CSR activities. Those are explained. This study is conducted with the objective of knowing the people/ client perception about the CSR as well as for knowing the bankers perception about the CSR activities. Today there is a strong competition prevailing among the banks, hence under the factor that impact on CSR activities of private and nationalized commercial banks towards the potential client which has great impression to enhance the banking activities as well as to continue of economic wheel and to improve the welfare of society. So under this scenario it is needed to know the present situation of CSR activities in context of private and nationalized commercial banks.

\section{Objectives of the Study}

The general objective of the study is to investigate the corporate social responsibility performed by banking sector of Bangladesh. Over and above the researcher reviews the following objectives.

- To identify the differences between the perception level of bankers' and people relating to CSR activities with nationalized and private banks of specific data.

- $\quad$ To find out the major areas where CSR activities are performing by nationalized and private banks.

- To compare the contribution of CSR activities of nationalized and private banks. 
- To suggest some possible modest measure to the authority concerned to perform CSR.

\section{Scope of the Study}

The study covered the following areas, an overview of CSR, an introduction of banks governance and accountability of CSR to the society, an analytical analysis of different contribution of CSR to the society, the time horizon the study is 2009 to 2013.

\section{Limitation of the study}

I have faced some problems, which may be termed as the limitations. Those are as follows.

$>$ To get clear knowledge is any field requires sufficient time. I have got only six month that is actually limited time to me to conduct research in vast area.

$>$ The research is mainly based on published annual report. But for the preparation of the research paper, I cannot get sufficient official data and information.

$>$ Sometimes officer and employees of bank do not want to give necessary information and data because of secrecy.

\section{Methodology}

At present there are many Commercial Banks in Bangladesh comprising of nationalized commercial banks, private commercial banks and foreign commercial banks. The available information suggests that most of the banks were responding to CSR performance. But we have been selected four Commercial Banks sample for the study. Sample selection has been made as per stratified Sampling process taking from four banks respectively. To select the sample at first researcher had divided two stratum nationalized and private commercial banks. Then from each group stratifying random sample has been made. The study based on primary and secondary data. Primary data have been collected by using questionnaires on five point Likert's Scale and secondary data have been collected from different secondary sources i.e. annual report, review of CSR, journal Banks' websites, Bangladesh Bank's Publications, newspapers. I have used statistical tools to find out respective contribution at percentage, mean, standard deviation, coefficient of variation. A list of related articles from various journals is also used to develop the basic idea about the particular topic for developing and implementing CSR standards and guidelines examine.

\section{ANALYSIS AND INTERPRETATION OF DATA}

We have collected 15 bankers and equal number beneficiaries or people response to make the comparative study. On the basis of the data so collected, tabulation, analysis, and interpretation have been made as represented as follows.
Table- 3.1 Contribution to Education

\begin{tabular}{|l|c|c|c|c|c|}
\hline \multirow{2}{*}{ Options } & Value & \multicolumn{4}{|c|}{ Frequency } \\
\cline { 3 - 7 } & & \multicolumn{2}{|c|}{$\begin{array}{c}\text { People } \\
\text { perspective }\end{array}$} & \multicolumn{2}{|c|}{$\begin{array}{c}\text { Bankers } \\
\text { perspective }\end{array}$} \\
\hline Strongly agree & 5 & 0 & $0 \%$ & 1 & $6.7 \%$ \\
\hline Agree & 4 & 4 & $26.7 \%$ & 11 & $73.3 \%$ \\
\hline Neutral & 3 & 0 & $0 \%$ & 3 & $20 \%$ \\
\hline Disagree & 2 & 9 & $60 \%$ & 0 & $0 \%$ \\
\hline Strongly disagree & 1 & 2 & $13.3 \%$ & 0 & $0 \%$ \\
\hline Total & & 15 & 100 & 15 & 100 \\
\hline Mean value & & \multicolumn{2}{|c|}{2.93} & & 3.87 \\
\hline $\begin{array}{l}\text { Standard } \\
\text { deviation(SD) }\end{array}$ & & \multicolumn{2}{|c|}{1.223} & \multicolumn{2}{|c|}{.516} \\
\hline $\begin{array}{l}\text { Coefficient of } \\
\text { variation(CV) }\end{array}$ & & \multicolumn{2}{|c|}{1.495} & \multicolumn{2}{|c|}{} \\
\hline
\end{tabular}

\section{Interpretation}

It shows that $60 \%$ people are disagreed, $26.7 \%$ people are agreed, and $13.3 \%$ people are strongly disagreed about CSR for education level from the banks. On the other hand, $73.3 \%$ bankers are agreed, $20 \%$ are neutral, and $6.7 \%$ are strongly agreed in their opinion towards CSR for education level from the banks. The mean value of people response towards CSR for education level from the banks is 2.93, which lie in disagreed category, while mean value of banker is 3.87 which lie in agreed category of banker' opinion. The value of $\mathrm{CV}$ of Bankers perspective is lower than People perspective and it denotes that the banker perception of CSR for education is less deviated than people perception of CSR for education. So, it can be concluded that the banker perception of CSR for education is satisfactory level.

Table-3.2 Contribution to Health

\begin{tabular}{|l|c|c|c|c|c|}
\hline \multirow{2}{*}{ Options } & Value & \multicolumn{3}{|r|}{ Frequency } \\
\cline { 3 - 6 } & & \multicolumn{2}{|c|}{$\begin{array}{c}\text { People } \\
\text { perspective }\end{array}$} & \multicolumn{2}{|c|}{$\begin{array}{c}\text { Bankers } \\
\text { perspective }\end{array}$} \\
\hline Strongly agree & 5 & 1 & $6.7 \%$ & 0 & $0 \%$ \\
\hline Agree & 4 & 3 & $20 \%$ & 7 & $46.7 \%$ \\
\hline Neutral & 3 & 1 & $6.7 \%$ & 4 & $26.7 \%$ \\
\hline Disagree & 2 & 9 & $60 \%$ & 4 & $26.7 \%$ \\
\hline Strongly disagree & 1 & 1 & $6.7 \%$ & 0 & $0 \%$ \\
\hline Total & & 15 & 100 & 15 & 100 \\
\hline Mean value & & & 2.60 & & 3.20 \\
\hline $\begin{array}{l}\text { Standard } \\
\text { deviation(SD) }\end{array}$ & & \multicolumn{2}{|c|}{1.121} & \multicolumn{2}{|c|}{.862} \\
\hline $\begin{array}{l}\text { Coefficient of } \\
\text { variation(CV) }\end{array}$ & & \multicolumn{2}{|c|}{1.257} & \multicolumn{2}{|c|}{} \\
\hline
\end{tabular}

\section{Interpretation}

From the table in respect of people perception it is found that $60 \%$ respondents of CSR for health is so much satisfy to the society show their disagree, $20 \%$ agree, $6.7 \%$ strongly agree, and $6.7 \%$ and $6.7 \%$ respondents are respectively neutral and strongly disagreed. On the other hand, $46.7 \%$ bankers are agreed, and $26.7 \%$, are respectively neutral and 
disagreed. Here mean value of people perspective and bankers perspective are respectively 2.60and 3.20 indicate that CSR for health is satisfactory level to the society bankers perception strong position than people perception. The value of $\mathrm{CV}$ of Bankers perspective and People perspective are .743 and 1.257 accordingly. It is observed that the CV of Bankers perspective is lower than People perspective. That means the bankers are satisfied to provide CSR to the society.

Table-3.3 Contribution to Environment

\begin{tabular}{|l|c|c|c|c|c|}
\hline \multirow{2}{*}{ Options } & Value & \multicolumn{4}{|c|}{ Frequency } \\
\cline { 2 - 6 } & & \multicolumn{2}{|c|}{$\begin{array}{c}\text { People } \\
\text { perspective }\end{array}$} & \multicolumn{2}{|c|}{$\begin{array}{c}\text { Bankers } \\
\text { perspective }\end{array}$} \\
\hline Strongly agree & 5 & 2 & $13.3 \%$ & 4 & $26.7 \%$ \\
\hline Agree & 4 & 12 & $80 \%$ & 7 & $46.7 \%$ \\
\hline Neutral & 3 & 1 & $6.7 \%$ & 3 & $20 \%$ \\
\hline Disagree & 2 & 0 & $0 \%$ & 1 & $6.7 \%$ \\
\hline Strongly disagree & 1 & 0 & $0 \%$ & 0 & $0 \%$ \\
\hline Total & & 15 & 100 & 15 & 100 \\
\hline Mean value & & \multicolumn{2}{|c|}{4.07} & & 3.93 \\
\hline $\begin{array}{l}\text { Standard } \\
\text { deviation(SD) }\end{array}$ & & \multicolumn{2}{|c|}{.458} & & .884 \\
\hline $\begin{array}{l}\text { Coefficient of } \\
\text { variation(CV) }\end{array}$ & & \multicolumn{2}{|c|}{.210} & & \\
\hline
\end{tabular}

\section{Interpretation}

Table shows that $80 \%$ respondents are agreed and $13.3 \%$ and $6.7 \%$ respondents are respectively strongly agree and neutral in the people perception of CSR for environmental factors. On the other hand, $46.7 \%$ respondents are agreed, $26.7 \%$ are strongly agreed, and $20 \%$ and $6.7 \%$ are respectively neutral and disagreed in the banker's perception. The mean value of people response towards the effectiveness of CSR is environmental factors. The mean value of people perception and banker's perception in the field of environment factors of are respectively 4.07 and 3.93 which lies in agree category of People perspective and bankers perception. The coefficient of variation of People perspective and Bankers perspective of CSR for environmental factors are respectively .210 and .781 which indicate that the opinion of the CSR of environment factors people perception is less deviated than Bankers perspective.

Table-3.4 Contribution to Farmer welfare

\begin{tabular}{|l|c|c|c|c|c|}
\hline \multirow{2}{*}{ Options } & Value & \multicolumn{4}{|r|}{ Frequency } \\
\cline { 3 - 6 } & & \multicolumn{2}{|c|}{$\begin{array}{c}\text { People } \\
\text { perspective }\end{array}$} & \multicolumn{2}{|c|}{$\begin{array}{c}\text { Bankers } \\
\text { perspective }\end{array}$} \\
\hline Strongly agree & 5 & 4 & $26.7 \%$ & 5 & $33.3 \%$ \\
\hline Agree & 4 & 10 & $66.7 \%$ & 6 & $40 \%$ \\
\hline Neutral & 3 & 1 & $6.7 \%$ & 4 & $26.7 \%$ \\
\hline Disagree & 2 & 0 & $0 \%$ & 0 & $0 \%$ \\
\hline Strongly disagree & 1 & 0 & $0 \%$ & 0 & $0 \%$ \\
\hline Total & & 15 & 100 & 15 & 100 \\
\hline Mean value & & \multicolumn{2}{|c|}{4.20} & & 4.07 \\
\hline Standard deviation(SD) & & \multicolumn{2}{|c|}{.561} & & .799 \\
\hline Coefficient of variation(CV) & & \multicolumn{2}{|c|}{.314} & & .638 \\
\hline
\end{tabular}

\section{Interpretation}

Table shows that $66 \%$ respondents for farmer welfare are agreed, $26.7 \%$ respondents are strongly agreed and $6.7 \%$ are neutral regarding the contribution of economic development of the country in the view of people. On the other hand, $40 \%$ Bankers perspective are agreed, 33.3\% are strongly agreed and $26.7 \%$ Bankers show their neutrality. Here mean value of People perspective and Bankers perspective about Contribution to Farmer welfare are respectively $4.20 \%$ and $4.07 \%$. The CV is .314and .638 accordingly. It is observed that the CV of People perspective is less than the CV of Bankers perspective. So, we can conclude that the People perspective is more agreed than that Bankers perspective towards satisfaction regarding farmer welfare.

Table-3.5 Types of activities which is conducted by the respective bank

\begin{tabular}{|c|c|c|c|c|c|c|}
\hline S.N & CSR activities & SBL & DBBL & JBL & PBL & $\%$ \\
\hline 1 & $\begin{array}{l}\text { Engaged in clean water } \\
\text { management }\end{array}$ & - & - & - & - & 0 \\
\hline 2 & Engaged in afforestation & - & - & - & - & 0 \\
\hline 3 & Beautifications of cities & $\sqrt{ }$ & - & - & $\sqrt{ }$ & 50 \\
\hline 4 & Waste management & $\sqrt{ }$ & $\sqrt{ }$ & - & $\sqrt{ }$ & 75 \\
\hline 5 & Natural calamities & $\sqrt{ }$ & $\sqrt{ }$ & $\sqrt{ }$ & $\sqrt{ }$ & 100 \\
\hline 6 & $\begin{array}{l}\text { Mentally or physically } \\
\text { handicapped }\end{array}$ & - & $\sqrt{1}$ & - & - & 25 \\
\hline 7 & Education of rootless children & $\sqrt{ }$ & $\sqrt{ }$ & $\sqrt{ }$ & $\sqrt{ }$ & 100 \\
\hline 8 & $\begin{array}{l}\text { Accommodation for the } \\
\text { slum dwellers }\end{array}$ & - & - & - & - & 0 \\
\hline 9 & $\begin{array}{l}\text { Women's rights and anti- } \\
\text { dowry practices }\end{array}$ & - & - & - & - & 0 \\
\hline 10 & $\begin{array}{l}\text { Rehabilitation of } \\
\text { orphan/rootless children }\end{array}$ & $\sqrt{ }$ & $\sqrt{ }$ & $\sqrt{ }$ & $\sqrt{ }$ & 100 \\
\hline 11 & $\begin{array}{l}\text { Engaged in treating cleft } \\
\text { lips, cataract, cancer }\end{array}$ & - & $\sqrt{ }$ & - & - & 25 \\
\hline 12 & $\begin{array}{l}\text { Engaged in treating acid } \\
\text { victims }\end{array}$ & - & $\sqrt{ }$ & - & - & 25 \\
\hline 13 & $\begin{array}{l}\text { Birth control products with } \\
\text { a view to solving the } \\
\text { population problem and to } \\
\text { conduct camps for } \\
\text { voluntary sterilization }\end{array}$ & - & - & - & - & 0 \\
\hline 14 & 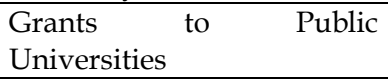 & - & $\sqrt{ }$ & - & - & 25 \\
\hline 15 & $\begin{array}{l}\text { Technical and vocational } \\
\text { education for meritorious poor }\end{array}$ & - & $\sqrt{ }$ & - & - & 25 \\
\hline
\end{tabular}

Try to verify contribution of banks in different areas of CSR. There are 15prescribed areas of CSR but only 10 areas are participated by four banks (67\%).So it is clear that 5 areas $(33 \%)$ there is no contribution from respective banks. There are only 3 areas $(100 \%)$ where each bank has participation and the lowest participation is 5 areas (25\%). Among the 4 banks DBBL has the highest participation areas (9) and JBL has the lowest participation areas (3). It is clear that participation of CSR areas of different bank is considerably limited because many areas where the bank has no CSR contribution that is very concerning issue. 
Table-3.6 Capital of each bank in respective year (million)

\begin{tabular}{|l|l|l|l|l|r|}
\hline Year & 2009 & 2010 & 2011 & 2012 & 2013 \\
\hline
\end{tabular}

\begin{tabular}{|l|c|c|c|c|c|}
\hline DBBL & $5,899.8$ & $9,125.9$ & 10534.9 & $12,284.00$ & 15403.357 \\
\hline
\end{tabular}

\begin{tabular}{|l|c|c|c|c|c|}
\hline SBL & 21495.07 & 30400.268 & 44208.881 & $(3345.095)$ & 28281.665 \\
\hline
\end{tabular}

\begin{tabular}{|l|r|c|c|c|c|}
\hline JBL & 5000.00 & 5000.00 & 8125.00 & 11000.00 & 19140.00 \\
\hline PBL & 15542.00 & 21485.00 & 24273.00 & 25752.00 & 26495.00 \\
\hline
\end{tabular}

\begin{tabular}{|l|l|l|l|l|l|}
\hline PBL & 15542.00 & 21485.00 & 24273.00 & 25752.00 & 26495.00 \\
\hline
\end{tabular}

Sources: Annual report in respective year 2009-2013

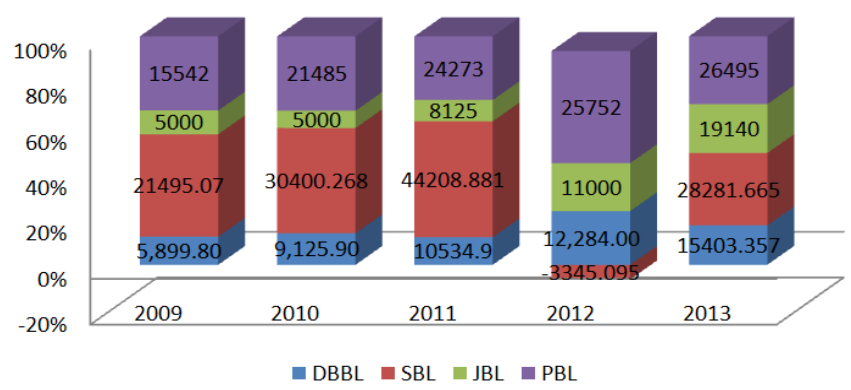

Figure: No: 3.1 graphically present of Capital of each bank in respective year (million)

\section{Interpretation}

It shows that the total capital of four banks in the respective year from 2009-2013.In respect of DBBL the highest capital of bank in the year of 2013 and lowest capital of 2009. DBBL has contributed to the CSR in the year of 2013(percentage of capital 1.228\%). SBL is the highest capital of bank in the year of 2011 as well as lowest capital of 2012. SBL has contributed to the CSR in the year of 2013(percentage of capital $0.0838 \%$ ). JBL is the highest capital of bank in the year of 2013 and lowest capital of $2009 \& 2010$. JBL has contributed to the CSR in the year of 2013(percentage of capital 1.527\%).In respect of PBL the highest capital of bank in the year of 2013 and lowest capital of 2009. PBL has contributed to the CSR in the year of 2013(percentage of capital $0.0357 \%$ )

Table-3.7 Net Earnings of each bank in respective year (million)

\begin{tabular}{|l|c|c|c|c|c|}
\hline $\begin{array}{l}\text { Name of } \\
\text { banks }\end{array}$ & 2009 & 2010 & 2011 & 2012 & 2013 \\
\hline DBBL & 1800.57 & 2002.32 & 2154.889 & 2314.103 & 2000.103 \\
\hline SBL & 3490.198 & 2337.610 & 995.72 & $(31533.546)$ & 3580.184 \\
\hline JBL & 2982.00 & 4907.00 & 4444.91 & 16501.52 & 9608.38 \\
\hline PBL & 2784.22 & 3002.88 & 3662.00 & 2699.00 & 1829.00 \\
\hline
\end{tabular}

Sources of annual report from 2009-2013

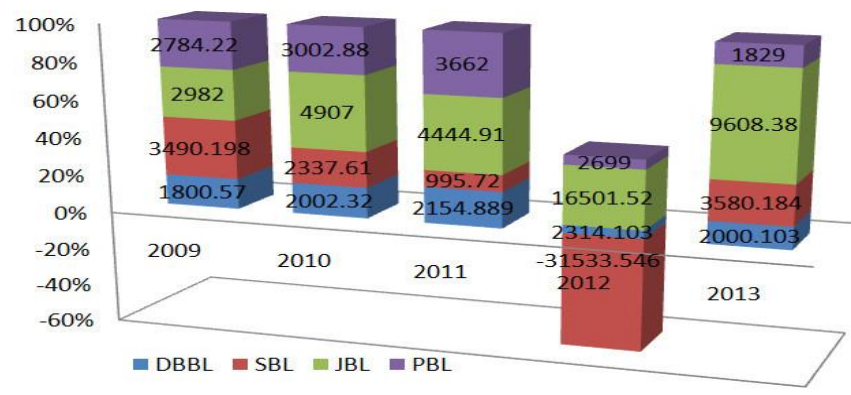

Figure: No: 3.2 graphically present the Net Earnings of each bank in respective year (million)

\section{Interpretation}

It shows that the net earnings of four banks in the respective year from 2009-2013.In respect of DBBL the highest net earnings of bank in the year of 2012 and lowest net earnings of 2009. DBBL has contributed to the CSR in the year of 2013(percentage of net earnings 9.46\%). In respect of SBL the highest net earnings of bank in the year of 2013 and lowest net earnings of 2012. SBL has contributed to the CSR in the year of 2013(percentage of net earnings $0.662 \%$ ). In respect of JBL the highest net earnings of bank in the year of 2012 and lowest net earnings of 2009. JBL has contributed to the CSR in the year of 2013(percentage of net earnings $3.04 \%$ ).In respect of PBL the highest net earnings of bank in the year of 2011 and lowest net earnings of 2013. PBL has contributed to the CSR in the year of 2013(percentage of net earnings $0.517 \%$ ).

Table-3.8 Total Contribution of CSR of four banks (million)

\begin{tabular}{|l|c|c|c|c|c|}
\hline Year & 2009 & 2010 & 2011 & 2012 & 2013 \\
\hline DBBL & 84.97 & 125.43 & 146.84 & 202.54 & 189.11 \\
\hline SBL & 15.99 & 23.33 & 50.00 & 00 & 23.69 \\
\hline JBL & 17.07 & 61.28 & 68.8 & 113.38 & 292.28 \\
\hline PBL & 10.52 & 21.37 & 35.92 & 16.81 & 9.45 \\
\hline
\end{tabular}

Sources of annual report from 2009-2013

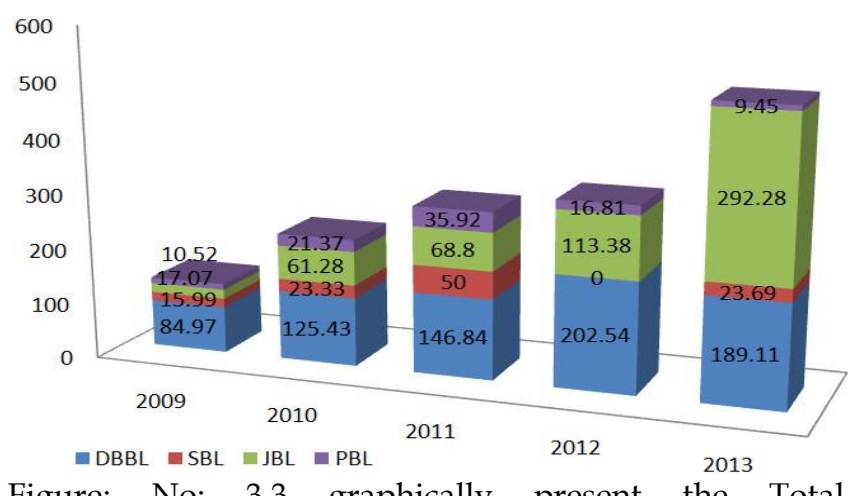
Figure: No: 3.3 graphically present the Total Contribution of CSR of four banks (million)

\section{Interpretation}

It shows that the total contribution of four banks in CSR in the respective year 2009-2013. DBBL is clearly ahead then others. Most of the banks contribution is less than $50 \%$ of DBBL. DBBL In the year 2013 the CSR is less the year of 2012, but chronologically it has increased. Lowest contribution is Prime bank where Janata bank in second position among the four Banks.

Table-3.9 Contribution to Education (million)

\begin{tabular}{|l|l|l|l|}
\hline Name of banks & 2009 & 2010 & 2011 \\
\hline DBBL & 45.75 & 50.16 & 46.38 \\
\hline SBL & 8.18 & 16.21 & 19.28 \\
\hline JBL & 5.54 & 6.77 & 12.41 \\
\hline PBL & 6.76 & 11.15 & 11.39 \\
\hline
\end{tabular}

Sources of annual report 2009-2011 


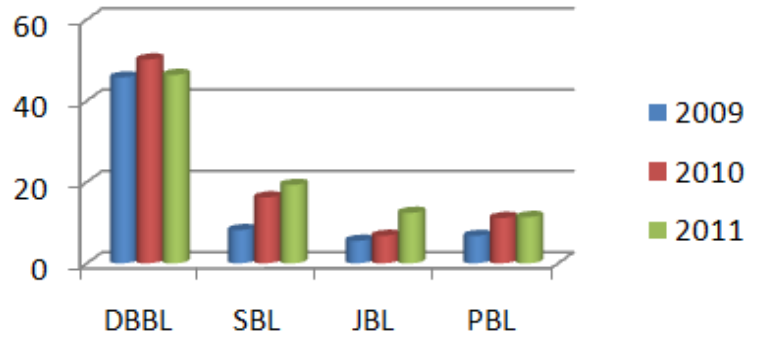

Figure: No: 3.4 graphically present the Total Contribution to Education (million)

\section{Interpretation}

It indicates that the contribution of education areas of 4 banks where DBBL shows a strong contribution then other banks. The total contribution of education in the year 2009 to 2011 is increased, but DBBL in the year of 2011 decreased the CSR expenses. Among those banks, not a single bank is nearer to DBBL where DBBL contributes more than $59 \%$ of total contribution. Sonali bank is in the second position and lowest contribution is Janata bank both 2009 and 2011.

Table-3.10 Contribution to Health (million)

\begin{tabular}{|l|l|l|l|}
\hline Name of banks & 2009 & 2010 & 2011 \\
\hline DBBL & 32.02 & 27.02 & 31.71 \\
\hline SBL & 2.71 & 3.75 & 2.81 \\
\hline JBL & 4.18 & 15.99 & 21.89 \\
\hline PBL & 3.76 & 5.25 & 4.25 \\
\hline
\end{tabular}

Sources of annual report 2009-2011

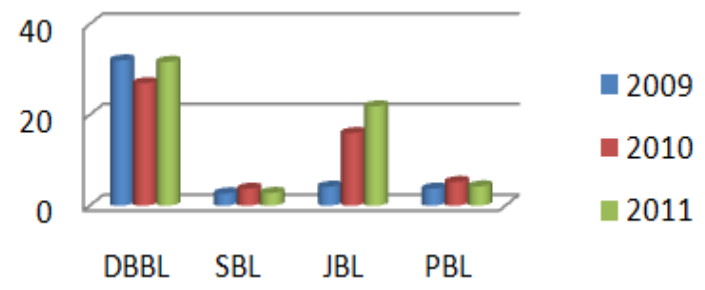

Figure: No: 3.5 graphically present the Total Contribution to Health (million)

\section{Interpretation}

It describes the present scenario of health areas of four banks. DBBL also in the top ranking, in the year of 2010 it has decreased but its participation is high rather than other bank where Sonali bank participation is lowest position. The second position of CSR in health contribution is Janata bank. On the other hand DBBL has the highest contribution amount then other banks.

Table-3.11 Contribution to natural disaster (million)

\begin{tabular}{|l|l|l|l|}
\hline Name of banks & 2009 & 2010 & 2011 \\
\hline DBBL & 3.75 & 4.5 & 4.98 \\
\hline SBL & 0.10 & 0.10 & .24 \\
\hline JBL & 00 & 11.1 & 7.5 \\
\hline PBL & 3.12 & 5.18 & 6.45 \\
\hline
\end{tabular}

Sources of annual report 2009-2011

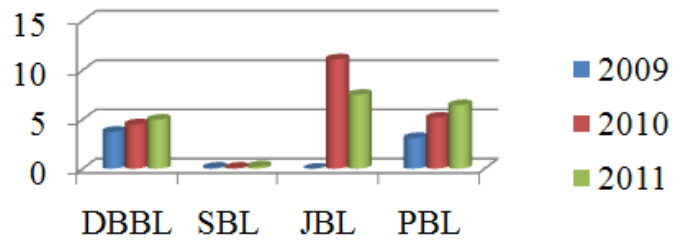

Figure: No: 3.6 graphically present the Total Contribution to natural disaster (million)

\section{Interpretation}

Presents CSR contribution of different banks in the area of natural disaster in the year 2009- 2011.In the area every bank has participation. Janata bank (39.56\%) is comparatively ahead than other banks. Prime bank also shows a good participation where total participation is $31.37 \%$ and the lowest position is Sonali bank in the respective year of 2009-2011.

Table-3.12 Farmer Welfare (million)

\begin{tabular}{|l|l|l|l|}
\hline Year & 2009 & 2010 & 2011 \\
\hline DBBL & 3.75 & 4.5 & 5.48 \\
\hline SBL & .10 & .10 & .21 \\
\hline JBL & 0 & .49 & 2.27 \\
\hline PBL & 0 & 0 & .07 \\
\hline
\end{tabular}

Sources of annual report 2009-2011

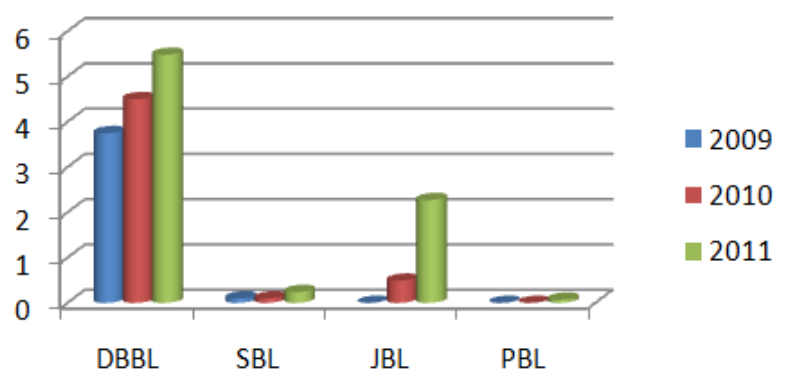

Figure: No: 3.7 graphically present the Total Contribution to Farmer Welfare (million)

\section{Interpretation}

It shows the contribution of farmer welfare of four banks in the year of 2009- 2011. In the area DBBL has highest participation in 2009-2011.It contribution is chronologically increased form the year of 2009-2011. In the area every bank has participation, but DBBL bank $(80.91 \%)$ is comparatively ahead than other banks. Second position is Janata bank to contribute the CSR in the sector of farmer welfare and lowest position of Prime bank. 
Table no: 3.13 Contribution to CSR activities of nationalized commercial banks (million)

\begin{tabular}{|c|c|c|c|c|c|c|c|c|c|c|}
\hline \multirow[t]{3}{*}{ Year } & \multicolumn{5}{|c|}{ Sonali bank } & \multicolumn{5}{|c|}{ Janata bank } \\
\hline & \multirow[t]{2}{*}{ capital } & \multirow[t]{2}{*}{$\begin{array}{c}\text { Net } \\
\text { earning }\end{array}$} & \multirow{2}{*}{$\begin{array}{c}\text { Total } \\
\text { Contribution } \\
\text { to CSR }\end{array}$} & \multicolumn{2}{|c|}{$\begin{array}{l}\text { Contribution } \\
\text { to CSR }\end{array}$} & \multirow[t]{2}{*}{ capital } & \multirow[t]{2}{*}{$\begin{array}{c}\text { Net } \\
\text { earning }\end{array}$} & \multirow{2}{*}{$\begin{array}{c}\text { Total } \\
\text { Contribution } \\
\text { to CSR }\end{array}$} & \multicolumn{2}{|c|}{$\begin{array}{c}\text { Contribution } \\
\text { to CSR }\end{array}$} \\
\hline & & & & $\begin{array}{c}\% \text { of } \\
\text { capital }\end{array}$ & $\begin{array}{l}\% \text { of net } \\
\text { earning }\end{array}$ & & & & $\begin{array}{c}\% \text { of } \\
\text { capital }\end{array}$ & $\begin{array}{l}\% \text { of net } \\
\text { earning }\end{array}$ \\
\hline 2009 & 21495.07 & 3490.19 & 15.99 & 0.074 & $\begin{array}{l}0.458 \\
\end{array}$ & 5000.00 & 2982.0 & 17.07 & 0.341 & 0.572 \\
\hline 2010 & 30400.26 & 2337.61 & 23.33 & 0.077 & 0.998 & 5000.00 & 4907.0 & 61.28 & 1.226 & 1.249 \\
\hline 2011 & 44208.88 & 995.72 & 50.00 & 0.113 & 5.02 & 8125.00 & 4444.9 & 68.8 & 0.847 & 1.548 \\
\hline 2012 & $(3345.09)$ & $(31533.5)$ & - & - & - & 11000.0 & 16501.5 & 113.38 & 1.031 & 0.687 \\
\hline 2013 & 28281.66 & 3580.18 & 23.69 & 0.084 & 0.662 & 19140.00 & 9608.38 & 292.28 & 1.527 & 3.04 \\
\hline
\end{tabular}

\section{Interpretation}

Table no 3.13 show that the Yearly performance of the selected nationalized commercial banks in CSR activities. It shows that the yearly CSR expenditures of the selected nationalized commercial banks .It also show that the contribution of CSR on percentage of total capital and net earnings in respective year2009-2013 of nationalized commercial banks. In respect of Sonali bank the contribution of CSR has increased in the respective year of 2009-2011 on the basis of capital and net earnings but 2012 did not contribute to the CSR due to negative balance and in the year of 2013 it has contributed of CSR on the basis of capital and net earnings. In respect of Janata bank has also contributed to the CSR in respective year 2009-2013, on the basis of capital the contribution of CSR has increased in the year of 2009-2010,decrease the contribution on CSR in the year of 2011 and next two year has increased the contribution on CSR. On the basis of net earnings the contribution of CSR has increased in the respective year 2009-2011, but in the year of 2012 has decreased contribution on CSR and in the year of 2013 has increased the contribution in the field of CSR.

Table no: 3.14 Contribution to CSR activities of private commercial banks (million)

\begin{tabular}{|c|c|c|c|c|c|c|c|c|c|c|}
\hline \multirow[t]{3}{*}{ Year } & \multicolumn{5}{|c|}{ Dutch Bangla Bank } & \multicolumn{5}{|c|}{ Prime Bank } \\
\hline & \multirow[t]{2}{*}{ Capital } & \multirow[t]{2}{*}{\begin{tabular}{|c|} 
Net \\
earning
\end{tabular}} & \multirow{2}{*}{$\begin{array}{c}\text { Total } \\
\text { Contribution } \\
\text { to CSR }\end{array}$} & \multicolumn{2}{|c|}{$\begin{array}{c}\text { Contribution } \\
\text { to CSR }\end{array}$} & \multirow[t]{2}{*}{ capital } & \multirow[t]{2}{*}{\begin{tabular}{|c|} 
Net \\
earning
\end{tabular}} & \multirow{2}{*}{$\begin{array}{c}\text { Total } \\
\text { Contribution } \\
\text { to CSR }\end{array}$} & \multicolumn{2}{|c|}{$\begin{array}{c}\text { Contribution } \\
\text { to CSR }\end{array}$} \\
\hline & & & & \begin{tabular}{|c|}
$\%$ of \\
capital
\end{tabular} & $\begin{array}{l}\% \text { of net } \\
\text { earning }\end{array}$ & & & & $\begin{array}{c}\% \text { of } \\
\text { capital }\end{array}$ & $\begin{array}{l}\% \text { of net } \\
\text { earning }\end{array}$ \\
\hline 2009 & $5,899.8$ & 1800.57 & 84.97 & 1.440 & 4.719 & 15542.00 & 2784.22 & 10.52 & 0.0677 & 0.378 \\
\hline 2010 & $9,125.9$ & 2002.32 & 125.43 & 1.374 & 6.264 & 21485.00 & 3002.88 & 21.37 & 0.0995 & 0.712 \\
\hline 2011 & 10534.9 & 2154.889 & 146.84 & 1.394 & 6.814 & 24273 & 3662.00 & 35.92 & 0.148 & 0.981 \\
\hline 2012 & $12,284.00$ & 2314.103 & 202.54 & 1.649 & 8.752 & 25752.00 & 2699.00 & 16.81 & 0.0653 & 0.623 \\
\hline 2013 & 5403.357 & 2000.103 & 189.11 & 1.228 & 9.455 & 26495.00 & 1829.00 & 9.45 & 0.0357 & 0.517 \\
\hline
\end{tabular}

\section{Interpretation}

Table no 3.14 shows that the Yearly performance of the selected private commercial banks in CSR activities. It shows that the yearly CSR expenditures of the selected private commercial banks .It also show that the contribution of CSR on percentage of total capital and net earnings in respective year2009-2013 of private commercial banks. In respect of Dutch Bangla bank the contribution of CSR has increased in the year of 2009, decreased the contribution in the year of 2010, next two year has increased the contribution on CSR and the year of 2013 has decreased the contribution on CSR by the Dutch bangle bank on the basis of capital. On the basis of net earnings the contribution of CSR has increased in the respective year 2009-2011, but decreased the contribution in the year of 2012 and increased the contribution in the year of 2013.In respect of prime bank the contribution of CSR has increased in the respective year 2009-2011, but in the year 2012-2013 has decreased the contribution on CSR on the basis of capital. On the basis of net earnings the contribution on CSR has increased in the respective year 2009-2011, it has decreased the contribution on CSR in the respective year 2012-2013.

\section{FINDINGS AND RECOMMENDATION}

\section{Findings}

The corporate social responsibility disclosures contained with the annual Reports of selected nationalized and private commercial banks which focus on social impacts, programs and policies. There was no direct evidence that corporate social responsibility disclosures are occur in response to peer or regulatory Pressure. If this was occurring, the pressure is arguably weak, as in one of the cases Examined no disclosure at all occurred. More likely, the disclosures are an attempt by the Banks to convey their corporate conscience. More finding is follow; DBBL contributes (9.455\%) of net earnings to CSR activities on the other hand JBL (3.04\%), PBL (0.517\%) $\mathrm{SB}(0.662 \%)$. It is very concerning that all banks contributes a little amount of net earnings to CSR. From the study it is clear that participation of different areas of 
CSR activities of different banks is limited. A prescription has given where there are (15)prescribed areas of CSR but only(10) areas are participated by four banks $(67 \%)$.So it is clear that 5 areas $(33 \%)$ there is no contribution from respective banks. There are only 3 areas $(100 \%)$ where each bank has participation and the lowest participation is 5 areas (25\%). Among the 4 banks DBBL has the highest participation areas (9) and JBL has the lowest participation areas (3). It is clear that participation of CSR areas of different bank is considerably limited because many areas where the bank has no CSR contribution that is very concerning issue.

\section{Recommendations}

I have identified some necessary activities which are needed to conduct CSR. At this stage; I like to give some recommendations for nationalized and private banks as follows:

\section{For the Banking Companies}

- Contribution should be extended to the root level by the nationalized and private commercial banks

- Increase the area of CSR by the nationalized banks as well as private banks such as poverty alleviation, healthcare, education, charity activities, and culture enrichment.

- Banks should provide the best service possible to the clients.

- Establish a fund to support the victim of natural disaster by nationalized and private commercial banks.

- Donate in the eco-friendly organization.

- Ensure those investments that are not harmful for the banks as well as their clients and environment.

- As both the civil society group and workers hold negative opinions about the corporate responsibility, banks have to seriously consider how to restore their image through CSR.

- Environmental concerns should receive greater attention by the banks.

- Bank-community relations are found to be strained. The Bank management and executives should consult and communicate with the local communities on a regular basis.

- Health and safety issues deserve greater attention given that failure in these areas impact negatively on the productivity and endanger human life.

For the Civil Society

- Should enhance their participation as a client in the banking affairs for holding the banks entities accountable to the greater segment of the general population.

- Should contribute to the process of awareness building of all the client or general people so that the banks do not function in an exploitative condition.

- Should contribute to the process of multi-sectors exchange of views and ideas in terms of both initiating and banking multi-sectored forums.

- Policy advocacy.
For the Government:

- Provide policy guidelines for smooth functioning of the banking entities about CSR.

- Monitor and enforce laws related to social issues, environment protection, and health.

- Provide the logistic support for enhancing the overall banking sector and carefully monitor the initiatives the corporate social responsibility.

- Setting achievable goals and ensuring appropriate monitoring systems in the banks to look into the corporate-social affairs.

- Ensuring financial independence of banks; and promoting Transparency and accountability of corporate as well as public entities.

- Encourage the development and diffusion of environment-friendly technologies.

- Undertake initiatives to promote greater environmental responsibility.

\section{ConcLusion}

This is true that banks are paying more to their CSR activities but not so much as their earnings increases. Common CSR practices in Bangladesh by different banks are centered on mainly poverty alleviation, healthcare, education, charity activities, cultural enrichment, youth development, women empowerment, patronizing sports and music etc. It is found in the study that CSR investments as percentage of total investment of the respective banks have been very meager during the study period. But, it is the demand of the age that more and more investments need to be made in all the organizations especially in the banks, the service rendering industry for the fulfillment of CSR of the organization. It is a matter of thinking that banks. As a third world country Bangladesh has lot of problems. As banking sectors of our country are considered as a part of the affluent section of the society they can contribute more meaningfully towards of the betterment of the society. If more company came forward to contribute to the society like DBBL, it will help to create their social branding as well as helping the society. According to the selected banks, we can say DBBL is a pioneer in Corporate Social Responsibility in our country.

\section{REFERENCES}

Azim, Mohammad I., Shaila Ahmed, and Md Shahidul Islam. "Corporate social reporting practice: evidence from listed companies in Bangladesh." Journal of Asia-Pacific Business 10.2 (2009): 130-145.

Belal, Ataur Rahman, and Stuart Cooper. "Absence of corporate social reporting (CSR) in Bangladesh: a research note." 5th Asia Pacific Interdisciplinary Research in Accounting Conference, 2007.

Belal, Ataur Rahman. Corporate social responsibility reporting in developing countries: The case of Bangladesh. Ashgate Publishing, Ltd., 2008. 
Chatterjee, Charles, and Anna Lefcovitch. "Corporate social responsibility and banks" Amicus Curiae 2009.78 (2009): 24-28.

Fenwick, Colin, et al. "Labor and labor related laws in small and micro enterprises: innovative regulatory responses." SEED (Geneva: International Labor Organization) (2008).

Gray, Rob, Dave Owen, and Keith Maunders. "Corporate social reporting: emerging trends in accountability and the social contract." Accounting, Auditing \& Accountability Journal 1.1 (1988): 6-20.

Holme, Richard, and Phil Watts. "Corporate social responsibility" Geneva: World Business Council for Sustainable Development (1999).

Hossain, Sarker Fouad. "Corporate social responsibility of private banks in Bangladesh: Expectations, achievements and challenges." Journal of Public Administration and Governance 2.1 (2012): 176-187.

Jamali, Dima, and Ramez Mirshak. "Corporate social responsibility (CSR): Theory and practice in a developing country context." Journal of business ethics 72.3 (2007): 243-262.

Khan, Habib-Uz-Zaman, Abdel K. Halabi, and Martin Samy. "Corporate social responsibility (CSR) reporting: a study of selected banking companies in Bangladesh." Social responsibility journal 5.3 (2009): 344-357.

Khan, Habib-Uz-Zaman, et al. "Corporate sustainability reporting of major commercial banks in line with GRI: Bangladesh evidence." Social responsibility journal 7.3 (2011): 347-362.

Khan, Habib-Uz-Zaman. "The effect of corporate governance elements on corporate social responsibility (CSR) reporting: Empirical evidence from private commercial banks of Bangladesh." International Journal of Law and Management 52.2 (2010): 82-109.

MacDonald, Kate. "Globalizing justice within coffee supply chains? Fair Trade, Starbucks and the transformation of supply chain governance." Third World Quarterly 28.4 (2007): 793-812.

Mantovan, Franco, et al. "[Interventions and their effects on informal caregivers of people with dementia: a systematic literature review]." Pflege 23.4 (2010): 223-239.

Matten, Dirk, and Jeremy Moon. "“Implicit" and "explicit" CSR: a conceptual framework for a comparative understanding of corporate social responsibility." Academy of management Review 33.2 (2008): 404-424.

Scholtens, Bert. "Corporate social responsibility in the international banking industry" Journal of Business Ethics 86.2 (2009): 159-175.

Scholtens, Bert. "Finance as a driver of corporate social responsibility." Journal of business ethics 68.1 (2006): 19-33.

Simpson, W. Gary, and Theodor Kohers. "The link between corporate social and financial performance: evidence from the banking industry." Journal of business ethics 35.2 (2002): 97-109.

Turker, Duygu. "Measuring corporate social responsibility: A scale development study" Journal of business ethics 85.4 (2009): 411-427.

Wise, Victoria, and Muhammad Ali. "Corporate governance and corporate social responsibility in Bangladesh with special reference to commercial banks."(2009).

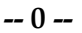


Publish Online and Print Version Both

Online ISSN: $\mathbf{2 3 0 5 - 8 7 3 0}$

Online Archive: http://journals.abc.us.org/index.php/abr/issue/archive

Indexed Archive Links

OCLC WorldCat: http://goo.gl/vhQzla

Google Scholar: https://goo.gl/t23FeQ

abcGATE: http://goo.gl/E6WdgA

BASE: $\underline{\text { http://goo.gl/sEd0SZ }}$

\section{Worldcat Google scholar $a b c G A T E$ PBASE}

